\title{
Description of Elderly Independence Level in doing Daily Living Activity at Panti Wredha St. Yoseph Kediri
}

\section{Erva Elli Kristanti, Yoyok Febrijanto, Dian Taviyanda}

STIKES RS. Baptis Kediri

Email:

erva.kristini@gmail,com

Received : October $4^{\text {nd }} 2021$

Accepted : October $15^{\text {rd }} 2021$

Published : November $27^{\text {th }} 2021$

\begin{abstract}
The increasing number of elderly from year to year has an impact on increasing the accompanying degenerative diseases. In addition, the elderly tend to be at risk for emotional changes and even at risk for depression which can have an impact on disruption of daily activities (Kelliat (1996) in Yuli (2014). Activity needs are basic needs because they cover self-care needs which include: bathing, dressing, going to the toilet, transferring, continence, and eating (Tamher, Noorkasiani, 2009).

Based on WHO data (2007), it shows that psychosocial factors in elderly are problems that are very burdensome for their lives, which in turn affect physical, social and mental disorders. Some of these conditions can affect activity daily living. Where is the main activity for self-care which includes: bathing, dressing, going to the toilet, transferring, continence, and eating (Tamher, Noorkasiani, 2009).

The objective of this study was to identify the level of independence of the elderly in carrying out daily living activities at Panti Wredha St. Yoseph Kediri. The design used in this research was descriptive. The population was the elderly at Panti Wredha St. Yoseph Kediri. The samples were 30 respondents with a purposive sampling technique. The independent variable was a description of the level of independence in carrying out daily living activities. The results showed that there was elderly's independence level in carrying out daily living activities, namely light dependence as many as 11 people $(68.8 \%)$ and moderate dependence 5 people $(31.3 \%)$. In conclusion, elderly's independence level in carrying out ADL at Panti Wredha St. Yoseph Kediri, namely light- moderate dependence.
\end{abstract}

Keywords: Level of independence, activity daily living, elderly

Copyright @ 2021 IIK STRADA Indonesia All right reserved.

This is an open-acces article distributed under the terms of the Creative Commons AttributionShareAlike 4.0 International License.

\section{INTRODUCTION}

The increase in the number of elderly has an impact on the number of diseases experienced by elderly. Elderly are people who are going through a process of gradual change over a period of several decades. Old age is a normal stage of development that will be experienced by every individual who reaches old age and is a reality that cannot be avoided (Notoatmodjo, 2007). Growing old is a condition that occurs in human life. The aging process is a lifelong process that does not only start from a certain 
time, but starts from the beginning of life. Growing old is a natural process which means that a person has gone through the stages of his life, namely neonates, toddlers, preschoolers, schools, teenagers, adults and the elderly. This different stage begins both biologically and psychologically. Entering old age many experience setbacks such as physical decline, which is characterized by skin becoming wrinkled due to reduced vision, deteriorating vision, tooth loss, activity slows down, decreased appetite and other body conditions as well as suffer setbacks.

Diseases that are often experienced by the elderly include emotional changes and depression. Along with these emotional changes, it can also have an impact on changes in the fulfillment of personal needs, especially the fulfillment of needs in meeting the needs of daily activities. Activity Daily Living (ADL) is the main activity for self-care which includes: bathing, dressing, going to the toilet, transferring, continence, eating (Tamher, Noorkasiani, 2009). To improve the ability of ADL in elderly, it is necessary to have positive motivation and confidence so that elderly is able to do ADL independently.

Based on data from WHO (2007) related to the prevalence of elderly population increasing from year to year and has the most factors that bring problems to elderly, namely psychological factors. Psychological factors can put a burden on elderly lives.

The ability to move is a basic need that is absolutely expected by every human being. These abilities include standing, walking, working, eating, drinking, and so on. With activities, the body will become healthy, the respiratory and circulatory systems will function properly, and the body's metabolism can be optimal. In addition, the ability to move will also affect one's self-esteem and body image. In this case, the ability to move cannot be separated from an adequate nervous and musculoskeletal system (Lilis, Taylor, Lemonek, 1989 in Mubarak \& Chayatin, 2014).

Based on this background, the researchers conducted further research on description of elderly's independence level in doing ADL needs at Panti Wredha St. Yoseph Kediri.

\section{METHOD}

Research design was descriptive. The objective was to identify elderly's independence level in doing at Panti Wredha St. Yoseph Kediri. This research was conducted on August 27, 2020-September 27,2020 . The variable in this study was elderly's independence level in fulfilling ADL.

\section{RESULT \\ General data \\ Characteristics of Respondents}

Based on the results of the study, the respondents were aged 60 years and the oldest was at the age of 90 years. Respondents were all female as many as 16 respondents (100\%) and more than 50\% were married as many as 11 respondents (the average last elementary education was equivalent to more than $50 \%$ as many as 8 respondents (50\%), the frequency of visits was almost never as many as 9 respondents $(56 \%)$

\section{Specific Data}

Becoming a research respondent, minimum education was elementary school, good communication skills. The inclusion criteria were elderly at Panti Wredha St. Yoseph Kediri, who were willing and who met the inclusion criteria.

Based on these criteria, the samples in this study were 16 respondents. Data collection was carried out twice by measuring level of independence and fulfillment of (ADL) needs. 


\section{Characteristics of Elderly's Independence Level at Panti Wredha St. Yoseph Kediri}

\begin{tabular}{clcc}
\multicolumn{4}{l}{ Table 1.1 Elderly's Independence Level at Panti W } \\
\hline \multicolumn{3}{c}{ Independence Level } \\
\hline No & \multicolumn{1}{c}{ Category } & Frequency & $\mathbf{( \% )}$ \\
\hline 1 & Independence & 0 & 0 \\
\hline 2 & $\begin{array}{l}\text { Light } \\
\text { Dependence }\end{array}$ & 11 & 68,8 \\
\hline 3 & $\begin{array}{l}\text { Moderate } \\
\text { Dependence }\end{array}$ & 5 & 31,3 \\
\hline 4 & $\begin{array}{l}\text { Severe } \\
\text { Dependence } \\
\text { Total }\end{array}$ & 0 & 0 \\
\hline & 16 & 100
\end{tabular}

Based on table 1.1, it was found that the level of dependence of elderly at Panti Wredha St. Yoseph Kediri, most of them were light dependence as many as 11 respondents (68.8\%), less than half with moderate dependence level as many as 5 respondents (31.3\%)

\section{DISCUSSION}

Based on the results of the study, it was found that the level of independence of the elderly was mild. The minimum age of the respondent was 60 years and the maximum age of the respondent was 90 years. The majority of elderly with elementary school education level or the equivalent were 8 respondents (50\%) with a visit frequency of more than half who had never visited as many as $9(56 \%)$.

Elderly age ranges from 60-74 years. At this age was the initial age of the elderly where elderly in general began to experience setbacks in various aspects, namely physical, psychological, economic and social. This period was the beginning of elderly adapting to these changes. Changes that occurred in elderly include biological and psychological. Entering old age, there were many setbacks, such as physical decline, which was marked by the skin becoming wrinkled due to reduced vision, deteriorating vision, tooth loss, activity becomes slow, appetite decreases and other body conditions also decline (Padila, 2013). Other changes occurred in the musculoskeletal system where this system played an important role in the body, changes that appeared in the form of a decrease in muscle strength caused by a decrease in muscle mass (muscle atrophy), muscle size became smaller and a decrease in muscle mass occurred more in the lower extremities. Dead muscle cells were replaced by connective tissue and fat. Strength or the amount of force produced by muscles decreases with age. Lower extremity muscle strength decreased by $40 \%$ between the ages of 30 and 80 years

The results showed that the level of dependence of the elderly was mild and moderate. Elderly most had a mild level of dependence this was because physiologically elderly age was different from adult age in general. Elderly experienced a decrease in several body functions, namely physiologically in the musculoskeletal system. Changes in this function had an impact on the limitations of the function to meet daily needs. This change in function had an impact on the emergence of dependence on elderly. Changes in body functions also occurred due to increasing age which caused changes in body functions. In addition, the respondents were at the age of 60-74 years. Ages over 60 years had a tendency to experience changes in physical activity due to a decrease in the function of the musculoskeletal system which was assumed to have an impact on the level of mild-moderate dependence. With increasing age, changes in body functions occurred due to a physiological decrease in the number of cells and this had an impact on decreasing body functions. Decreased body functions caused health problems such as pain, joint stiffness and this was normally followed by physiological changes in the musculoskeletal system. Changes in the musculoskeletal system had an impact on reducing joint fluid which results in complaints of pain when moving. In addition, respondents were aged 60-74 years where at this age was the initial age of the elderly where the elderly in general began to experience setbacks in various aspects, namely physical, psychological, economic and social. This period was the beginning of the elderly adapting to these changes. This was in line with the results of research that elderly experienced physical decline and in the end, elderly had mild to severe dependence. 
The results showed that elderly also rarely met their family. Family visit was one part of family support, namely emotional support which was the application of a form of attention to elderly. This support was very helpful for elderly in having good motivation, especially in living every process of life. Meanwhile, respondents who had a low frequency of visits would lead to a condition of low attention which lead to a lack of motivation in living daily life. The impact that arose in this condition was the low motivation in fulfilling activities and was a triggering factor for the decreased independence of elderly as a result of the lack of attention to the respondents.

\section{CONCLUSION}

Most of the elderly at Panti Wredha St. Yoseph Kediri had a light-moderate dependence level in meeting the needs of daily activities. The elderly were at the age of 60-74 where at this age, elderly experienced a physiological decline in function, especially in meeting activity needs. In addition, the adjustment of the adaptation process to changes in function affected the level of independence of elderly at Panti Wredha St. Yoseph Kediri.

\section{SUGGESTION}

Nurses can continue to provide support to elderly in meeting the needs of activities, especially by involving the family in an effort to provide social support to the elderly. And they can provide an explanation that activity is an important thing that can support metabolism and the health of elderly.

\section{REFERENCES}

Barbara K. Haight (2016). The Therapeutic Role of a Structured Life Review Process in Homebound Elderly Subjects. College of Nursing, Medical University of South Carolina.

Dea, (2015). PengaruhTerapi Modalitas Life Review Terhadap Tingkat Stress Pada Lansia Di Panti Werdha Ilomata Kota Gorontalo. Jurnal Ungaran Gorontalo.

E. T. Bohlmeijer, G. J. Westerhof (2013). Life Review as a Way to Enhance Personal Growth in Midlife: A Case Study.Journal University of Twente.

Elizabeth, Corwin. (2000). Patofisiologis. Penerbit Buku Kedokteran. EGC. Jakarta.

FIK UI. (2005). Kumpulan Materi Keperawatan Neurologi. Jakarta.

Gofir, Abdul. (2009). Evidence Base Medicine ; Manajemen Stroke. Pustaka Cendekia Press. Yogyakarta

Iyus J, Titin S, (2014). Buku Ajar Keperawatan Jiwa. Bandung: Refika Aditama, hal: 281.

Keliat, B. A., Akemat., Helena, N, \& Nurhaeni, H. (2007). Keperawatan Kesehatan Jiwa Komunitas: CMHN (Basic Course). Jakarta: EGC

Manoj Sharma, AshutoshAtri, Paul Branseum (2013). Foundations of Health Promotion.Burlington: Jones \&Barlett Learning, L.L.C, an Aseend Learning Company.

Marjorie, Linda Norlander (2009), Being Present A Nurse's End of Life Communication. Canada: Sigma Theta Tau International.

Mubarak, W.I \& Chayatin, N. (2013). Ilmu keperawatan komunitas I. Jakarta : Salemba.

Muhammad, Sasmiyanto, Susi (2014). Pengaruh Life Review Therapy Terhadap Kualitas Hidup Lansia

Di Dinas Unit Pelaksana Teknis Pelayanan Sosial Lanjut Usia Kabupaten Bondowoso. Universitas Muhammadiyah Jember.

Notoatmodjo, S. (2010). Metodologi Penelitian Kesehatan. Jakarta : Rineka Cipta

Nursalam, (2013). Metodologi Penelitian Ilmu Keperawatan Pendekatan Praktis Edisi 3. Jakarta: Salemba Medika.

Nursalam, (2015). Metodologi Penelitian Ilmu Keperawatan Pendekatan Praktis Edisi 4. Jakarta: Salemba Medika.

Nursalam, (2016). Konsep dan Penerapan Metodologi Penelitian Ilmu Keperawatan. Jakarta: Salemba

Padila, (2013). Buku Keperawatan Gerontik. Yogyakarta: Nuha Medika

Robyn M, Josephine, Phyllis (2015). Therapeutic Life Review in Palliative Care: A systematic Review of Evaluations. Journals Universityof Sydney.

Setyoadi, Kusharyiadi (2011). Terapi Modalitas Keperawatan pada Klien Psikogeriatik. Jakarta: Salemba Medika. 
Sue Wheeler (2006), Difference AndDiversity in Councelling Contemporary Psychodynamic Perspectives. New York: Palgrav Macmillan.

Tamher, S \& Noorkasiani (2009). Kesehatan Usia Lanjut dengan pendekatan Asuhan Keperawatan. Jakarta : Salemba Medika

WHO. (1994). World Health Organization Quality of Life.WHO 